\section{Assessment of Heat-expanded Slate and Fertility Requirements in Green Roof Substrates}

\author{
D. Bradley Rowe ${ }^{1}$, Michael A. Monterusso ${ }^{2}$, and Clayton L. Rugh ${ }^{3}$
}

AdDitional InDEx wORDs. eco-roof, living roof, native species, PermaTill, plant evaluations, Sedum, succulents, vegetative roof

Summary. Green roof technology in the United States is in the early development stage and several issues must be addressed before green roofs become more widespread in the U.S. Among these issues is the need to define growing substrates that are lightweight, permanent, and can sustain plant health without leaching nutrients that may harm the environment. High levels of substrate organic matter are not recommended because the organic matter will decompose, resulting in substrate shrinkage, and can leach nutrients such as nitrogen $(\mathrm{N})$ and phosphorus $(P)$ in the runoff. The same runoff problems can occur when fertilizer is applied. Also, in the midwestern U.S., there is a great deal of interest in utilizing native species and recreating natural prairies on rooftops. Since most of these native species are not succulents, it is not known if they can survive on shallow, extensive green roofs without irrigation. Five planting substrate compositions containing $60 \%, 70 \%, 80 \%, 90 \%$, and $100 \%$ of heat-expanded slate (PermaTill) were used to evaluate the establishment, growth, and survival of two stonecrops (Sedum spp.) and six nonsucculent natives to the midwestern U.S. prairie over a period of 3 years. A second study evaluated these same plant types that were supplied with four levels of controlled-release fertilizer. Both studies were conducted at ground level in interlocking modular units $(36 \times 36$ inches $)$ designed for green roof applications containing $10 \mathrm{~cm}$ of substrate. Higher levels of heat-expanded slate in the substrate generally resulted in slightly less growth and lower visual ratings across all species. By May 2004, all plants of smooth aster (Aster laevis), horsemint (Monarda punctata), black-eyed susan (Rudbeckia birta), and showy goldenrod (Solidago speciosa) were dead. To a lesser degree, half of the lanceleaf coreopsis (Coreopsis lanceolata) survived in $60 \%$ and $70 \%$ heat-expanded slate, but only a third of the plants survived in $80 \%, 90 \%$, or $100 \%$. Regardless of substrate composition, both 'Diffusum' stonecrop ( $S$. middendorffianum) and 'Royal Pink' stonecrop ( $S$. spurium) achieved $100 \%$ coverage by June 2002 and maintained this coverage into 2004 . In the fertility study, plants that received low fertilizer rates generally produced the least amount of growth. However, water availability was a key factor. A greater number of smooth aster, junegrass (Koelevia macrantha), and showy goldenrod plants survived when they were not fertilized. Presumably, these plants could survive drought conditions for a longer period of time since they had less biomass to maintain. However, by the end of three growing seasons, all three nonsucculent natives also were dead. Overall results suggest that a moderately high level of heat-expanded slate (about $80 \%$ ) and a relatively low level of controlled-release fertilizer $\left(50 \mathrm{~g} \cdot \mathrm{m}^{-2}\right.$ per year) can be utilized for green roof applications when growing succulents such as stonecrop. However, the nonsucculents used in this study require deeper substrates, additional organic matter, or supplemental irrigation. By reducing the amount of organic matter in the substrate and by applying the minimal amount of fertilizer to maintain plant health, potential contaminated discharge of $\mathrm{N}, \mathrm{P}$, and other nutrients from green roofs is likely to be reduced considerably while still maintaining plant health.

$\mathrm{I}$ $\mathrm{n}$ addition to the aesthetic value and health benefits provided by green roofs, other benefits include the mitigation of stormwater runoff quantity and quality (Liesecke, 1998;

Michigan State University, East Lansing, MI 48824.

${ }^{1}$ Associate Professor, Department of Horticulture.

${ }^{2}$ Former Graduate Research Assistant, Department of Horticulture.

${ }^{3}$ Assistant Professor, Department of Crop and Soil Sciences.

Funding for this study was provided by Ford Motor Company, Dearborn, Mich.; McDonough Braungart Design Chemistry, Charlottesville, Va.; and the Michigan Agricultural Experiment Station.
Rowe et al., 2003; Schade, 2000; VanWoert et al., 2005a), improved air quality (Clark et al., 2005), a reduction in energy consumption for individual buildings as well as an overall reduction in the urban heat island effect (Connelly and Liu, 2005; Saiz-Alcazar and Bass, 2005), and protection of roof membranes from ultraviolet radiation and extreme temperature fluctuations, thus extending the lifespan of the roof (Giesel, 2001). Green roofs are becoming common in Germany and the rest of Europe (Boivin et al., 2001; Dunnett and Kingsbury, 2004); however, the concept is just now being introduced in the U.S.

In order for these benefits to be realized in North America, plant species must be identified that can withstand the harsh environmental conditions that are frequently present on rooftops (Dunnett and Kingsbury, 2004; Dunnett and Nolan, 2004). Some North American research on plant species has been completed in Quebec (Boivin et al., 2001) and studies have been initiated in Pennsylvania and Michigan (Durhman et al., 2004; Monterusso et al., 2005; Rowe et al., 2005; VanWoert et al., 2005b), where succulents such as stonecrop have dominated. However, in the midwestern U.S., there is a great deal of interest in utilizing native species to recreate natural prairies on green roof installations. Since most of these native species are not succulents, it is questionable whether they can withstand the environmental conditions typically found on shallow, extensive green roofs without irrigation. Those found to be suitable could expand the list of plant species and reduce the potential problems associated with monocultures of stonecrop. Also, growing substrates must be formulated that can sustain plant life with minimal maintenance requirements without creating environmental problems in the runoff, and yet be lightweight to stay within the load-bearing capacity of the building (Beattie and Berghage, 2004; Dunnett and Kingsbury, 2004; Friedrich, 2005).

The ideal substrate is comprised of a balance of lightweight, well-drained material, possesses adequate water and nutrient-holding capacity, will not break down over time, and will not

\begin{tabular}{llll}
\hline $\begin{array}{l}\text { Units } \\
\begin{array}{l}\text { To convert U.S. to SI, } \\
\text { multiply by }\end{array}\end{array}$ & U.S. unit & SI unit & $\begin{array}{l}\text { To convert SI to U.S., } \\
\text { multiply by }\end{array}$ \\
\hline 2.54 & inch $(\mathrm{es})$ & $\mathrm{cm}$ & 0.3937 \\
25.4 & inch $(\mathrm{es})$ & $\mathrm{mm}$ & 0.0394 \\
16.0185 & $\mathrm{lb} / \mathrm{ft}^{3}$ & $\mathrm{~kg} \cdot \mathrm{m}^{-3}$ & 0.0624 \\
305.1517 & $\mathrm{OZ} / \mathrm{ft}^{2}$ & $\mathrm{~g} \cdot \mathrm{m}^{-2}$ & 0.0033 \\
$\left({ }^{\circ} \mathrm{F}-32\right) \div 1.8$ & ${ }^{\circ} \mathrm{F}$ & ${ }^{\circ} \mathrm{C}$ & $\left(1.8 \times{ }^{\circ} \mathrm{C}\right)+32$
\end{tabular}


leach large quantities of nutrients into the runoff. Even though most plants prefer substrates with high organic matter content, high percentages of organic matter will decompose, causing substrate shrinkage, changes in aeration and water-holding capacity, and potential leaching of nutrients (Bilderback et al., 2005). It is also not feasible or practical to continually replace substrate on a rooftop. For these reasons, it is generally accepted that no more than $15 \%$ organic matter be used in green roof substrates. The major component should be mineral-based materials such as expanded slate, shale, clay, or other volcanic materials (Beattie and Berghage, 2004). Heat-expanded slate (PermaTill; Carolina Stalite, Salisbury, N.C.) shows potential because it is relatively lightweight, promotes good drainage, and is persistent.

In regard to nutrients, numerous studies have evaluated the role of controlled-release fertilizers (CRF) in producing optimal growth for containerized plants. In contrast to containerized nursery stock in a production schedule, maximum growth is not always desirable on a green roof. Greater biomass increases the static load placed on the building and lush growth is more vulnerable to stress related to rapid and extreme changes in temperature and moisture commonly found in rooftop environments. Ideally, a green roof fertilizer application schedule would utilize enough fertilizer to maintain acceptable plant health and aesthetics while minimizing the amount of runoff contamination. Emilsson (2004) studied three fertilization levels (low and medium rates of CRF and CRF in combination with water-soluble applications) on two types of green roof vegetation in Sweden (old prevegetated mats and fertilization of newly established green roofs). All had potential for nutrients leaching into stormwater runoff. In addition, in many cases medium to high fertility is not necessary and may be detrimental. A German study reported that stonecrop sprouts did not survive when strongly fertilized (Jauch, 1993), although the author does not indicate what is considered "strong."

Identifying suitable plants, developing lightweight yet persistent substrates capable of supporting acceptable plant health, and determining minimum maintenance requirements are important to promote the use of green roof technology. Therefore, the objectives of this research were to determine performance of selected species 1) in substrates composed of increasing levels of heat-expanded slate, and 2) when provided with various levels of CRF.

\section{Materials and methods}

Two studies were conducted over the course of 3 years (2001-04) to determine the effect of substrate composition and fertility levels on several potential species that may be suitable for extensive green roofs. Both studies were conducted in interlocking modular units designed for green roof applications (McDonough Braungart Design Chemistry, Charlottesville, Va.). The modular units measured 36 $\times 36$ inches and were placed at ground level on a gravel container pad at Michigan State University (East Lansing). Modular units were interlocked in one large group containing border rows.

SubSTRATE COMPOSITION STUDY. Twenty green roof modular units were filled with $10 \mathrm{~cm}$ of substrate that contained $60 \%, 70 \%, 80 \%, 90 \%$, or $100 \%$ of heat-expanded slate (PermaTill) with a particle size ranging from 7.9 to $9.5 \mathrm{~mm}$. The remaining volume of substrate in the $60 \%$ mixture consisted of $25 \%$ U.S. Golf Association (USGA)grade sand (Osburn Industries, Taylor, Mich.), 10\% Michigan peat (Osburn Industries, Taylor, Mich.), and 5\% aged compost. The compost consisted of aged poultry manure (Herbruck's Poultry Ranch, Saranac, Mich.) and composted yard waste (Charter Township of Ypsilanti, Ypsilanti, Mich.) mixed in a $2: 1$ ratio (by volume). The percentages of sand, peat, and compost decreased in equal proportions in the $70 \%, 80 \%, 90 \%$, and $100 \%$ heat-expanded slate mixtures (Table 1). Substrate bulk density $\left(130 \mathrm{~kg} \cdot \mathrm{m}^{-3}\right)$, capillary pore space $(19.9 \%)$, noncap- illary pore space $(21.4 \%)$, infiltration rate $\left(51.6 \mathrm{~cm} \cdot \mathrm{h}^{-1}\right)$, and water-holding capacity $(17.1 \%)$ of the $60 \%$ heat-expanded slate substrate at $0.01 \mathrm{MPa}$ were determined (A \& L Laboratories, Fort Wayne, Ind.). Bulk densities for the $70 \%, 80 \%, 90 \%$, and $100 \%$ heatexpanded slate substrates were 116, 103,90 , and $77 \mathrm{~kg} \cdot \mathrm{m}^{-3}$, respectively. At time of planting, each modular unit received Nutricote $13 \mathrm{~N}-5.7 \mathrm{P}-10.8 \mathrm{~K}$ Type 180 controlled-release fertilizer (Agrivert, Webster, Texas) and again $331 \mathrm{~d}$ after the study was initiated at a rate of $100 \mathrm{~g} \cdot \mathrm{m}^{-2}$.

Two distinct types of plants were used: two succulent species of stonecrop exhibiting Crassulacean Acid Metabolism, representing typical green roof plants used in the industry; and six herbaceous perennials and grasses native to the midwestern U.S. Species included 'Diffusum' stonecrop, 'Royal Pink' stonecrop, smooth aster, lanceleaf coreopsis, junegrass, horsemint, blackeyed susan, and showy goldenrod.

All plugs were planted 15 June 2001. One side of each green roof modular unit was selected at random and planted with four plugs of the two species of stonecrop on $30-\mathrm{cm}$ centers. The other side received three plugs of six nonsucculent native species planted on 18 -cm centers. The 20 modular units were arranged in a randomized complete-block design with four blocks, five substrate compositions as treatments, and either four or three replications of each species within each modular unit for the two stonecrops and six native species, respectively. The study utilized 80 plants of each of the two stonecrops and 60 plants of each of the six native species for a total of 520 plants.

FertiLizer study. Twelve interlocking green roof modular units were each filled with $10 \mathrm{~cm}$ of substrate containing $60 \%$ heat-expanded slate (as described previously) and were

Table 1. Percentage of heat-expanded slate, sand, peat, and compost in substrates utilized to evaluate the establishment, growth, and survival of two stonecrop species and six nonsucculent species native to the midwestern U.S. prairie.

\begin{tabular}{|c|c|c|c|c|c|}
\hline \multirow{2}{*}{$\frac{\text { Component }}{\text { Heat-expanded slate }^{\mathrm{z}}}$} & \multicolumn{5}{|c|}{ Substrate component (\%) } \\
\hline & 60 & 70 & 80 & 90 & 100 \\
\hline Sand ${ }^{y}$ & 25 & 18.75 & 12.5 & 6.25 & 0 \\
\hline Peat $^{x}$ & 10 & 7.5 & 5 & 2.5 & 0 \\
\hline Compost $^{\mathrm{w}}$ & 5 & 3.75 & 2.5 & 1.25 & 0 \\
\hline
\end{tabular}


planted with 'Diffusum' stonecrop, 'Royal Pink' stonecrop, smooth aster, junegrass, and showy goldenrod. Four levels of Nutricote $13 \mathrm{~N}-5.7 \mathrm{P}-10.8 \mathrm{~K}$ Type 180 controlled-release fertilizer were established as treatments: 0 (control), 50, 100, and $150 \mathrm{~g} \cdot \mathrm{m}^{-2}$. Fertilizer was applied at the time of planting (15 June 2001) and again on days 331 and 696.

Planting of plugs was as described previously, except five plants of each nonsucculent native species were placed within each modular unit. The 12 modular units were arranged in a randomized complete-block design with three blocks, four fertility levels as treatments, and either four or five replications of each species within each modular unit for the two stonecrops and three native species, respectively. The study utilized 48 plants of each stonecrop and 60 plants of each of the three native species for a total of 276 plants.

Irrigation. In both studies, an automated overhead irrigation system (Rainbird; Azusa, Calif.) was used to encourage plant establishment and coverage. The system was programmed to run for three 15-min cycles per day $(0900,1200$, and $1500 \mathrm{HR})$ from day 1 through 36 , two cycles per day ( 1000 and $1500 \mathrm{HR}$ ) from day 37 through 51 , and once per day (1200 HR) until irrigation was terminated for the first growing season on day 91 (13 Sept. 2001 ). Irrigation was resumed during the second season on day 362 ( 11 June 2002 ) and manually operated for one 15-min cycle per day as needed until it was terminated on day 390 (10 July 2002). Each cycle applied approximately $0.38 \mathrm{~cm}$ of water to each platform. No supplemental irrigation was supplied during the remainder of the second growing season and for the entire third year, so plants had to rely solely on natural rainfall.

Data Collection. Data on plant height and two-dimensional width were recorded monthly for each study during establishment and during the growing season over the course of 3 years. Establishment was defined as the period after planting, but prior to the first-year dormancy. A growth index was calculated for each plant by averaging the three individual growth measurements. Percent coverage was determined visually. The relative appearance of each plant was also evaluated at the time of measurement on a
0-5 scale: $0=$ dead, $1=$ stressed plant showing visible wilting or browning, 2 = a plant that showed little change since planting, 3 = slow growth, $4=$ healthy plant exhibiting a large amount of growth, and 5 = exceptional growth and fullness. Final growth measurements and survival data were recorded during Oct. 2003 and May 2004, respectively. Ambient air temperature and precipitation data were compiled from the Michigan Automated Weather Network's (MAWN) East Lansing, weather station, located adjacent to the research site. Air temperatures were recorded at $1.5 \mathrm{~m}$ aboveground.

Data Analysis. Both studies were arranged as a randomized completeblock design. For comparison of plant growth indices, a mixed model was fit with repeated measures and fixed effects of heat-expanded slate and fertilizer level (substrate composition and fertilizer study, respectively) and time (PROC GLM, SAS version 8.02; SAS Institute, Cary, N.C. ). An autoregressive (1) covariance structure was used and modular unit was treated as a random effect in both studies. To compare visual ratings, a generalized linear model with a multinomial error structure was fit with heat-expanded slate or fertilizer level as a fixed effect (PROC GENMOD). Differences between treatments were tested within each species using chi-squared tests. In all analyses, Tukey-Kramer adjustments were made to test for pairwise differences.

\section{Results and discussion}

During the first growing season (2001), plants in both studies peaked in size by September and receded with the onset of dormancy (Figs. 1 and 2 ). During the second season, plants of most species were at their peak growth and appearance in early July 2002. Favorable growth and appearance during the first season was possible because irrigation was provided during establishment. This was not the case during the second season as irrigation was much reduced and was terminated completely by 10 July 2002 (day 390). Therefore, plants had to rely on natural rainfall for the remainder of 2002 and for the entire 2003 season, a likely situation on most extensive green roofs. Following the termination of irrigation, plant size and appearance diminished greatly for native species, and many plants died or became dormant. However, both stonecrops continued to grow and were successful in withstanding this transition.

SubSTRATE COMPOSITION STUDY. No substrate composition was observed to produce consistently higher growth across all species. Except for junegrass, horsemint, and showy goldenrod, the $100 \%$ heat-expanded slate substrate generally resulted in the least amount of growth during the first 2 years $(P \leq 0.05)$ (Fig. 1$)$. By the end of the second season, both stonecrops reached $100 \%$ coverage regardless of substrate composition. During the third year, 'Diffusum' stonecrop displaced some of the 'Royal Pink' stonecrop as it was a more aggressive grower (Fig. 1). Lanceleaf coreopsis was marginally successful in tolerating the drought conditions present after supplemental irrigation was removed during the second season.

When plants were at their peak in early July 2002, plants grown in 100\% heat-expanded slate generally exhibited the lowest visual ratings (Table 2). Exceptions were junegrass, horsemint, and showy goldenrod, where no visual differences were observed among treatments, and black-eyed susan, which looked the best when grown in $80 \%$ and $90 \%$ heat-expanded slate. When averaged, 100\% heat-expanded slate produced the lowest visual rating across all treatments with a mean value of 2.51 (out of 5 ). Throughout the study, 'Diffusum' stonecrop and Royal Pink' stonecrop had the highest visual ratings of all species evaluated, as well as having the best drought tolerance after the termination of irrigation, based on visual appearance, growth, and survival. Neither was affected by the percentage of heat-expanded slate except at the $100 \%$ level.

Survival rates for all species were high during the establishment period (data not presented). Establishment was defined as the period after planting, but prior to winter dormancy. Lanceleaf coreopsis and black-eyed susan were the only species to exhibit establishment mortality with just one and two plants that died, respectively. Although a limited amount of mortality was observed, hot, dry weather prevailed during much of the first growing season that could have affected plant health during the establishment phase. During the 10-week period from 26 June through 6 Sept. 2001, total 

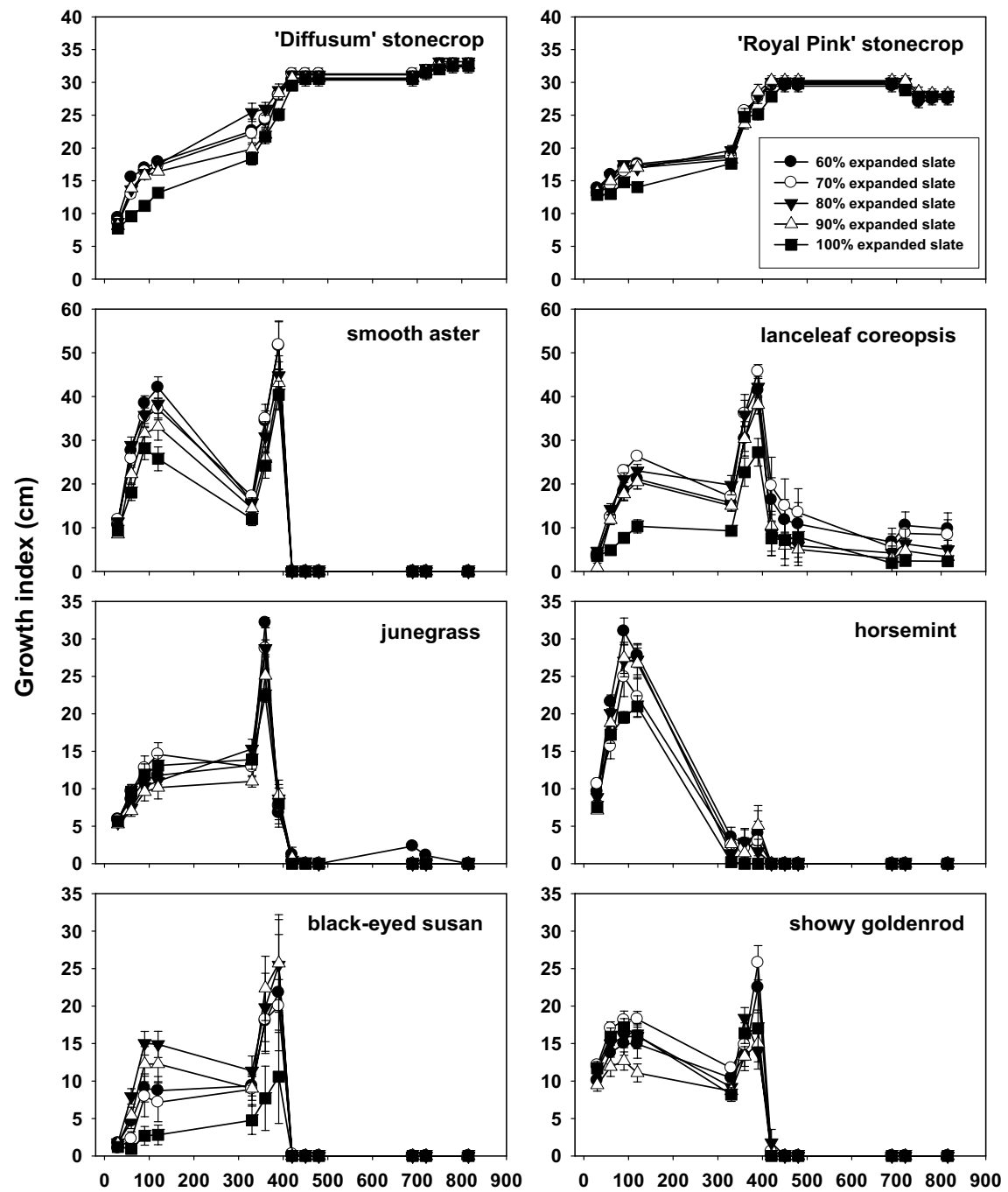

Time after study initiation (d)

Fig. 1. Growth index of two stonecrops and six nonsucculent species native to the midwestern U.S. prairie cultivated in different substrate compositions with increasing levels of heat-expanded slate with a particle size ranging from 7.9 to $9.5 \mathrm{~mm}(0.31$ to 0.37 inch $)$. The $60 \%$ substrate was composed of $60 \%$ heat-expanded slate, $25 \%$ U.S. Golf Association-grade sand, $\mathbf{1 0 \%}$ peat, and $\mathbf{5 \%}$ compost. The $70 \%, 80 \%, 90 \%$, and $100 \%$ substrates had proportional decreases in sand, peat, and compost. Measurements on plant size were taken monthly during three growing seasons. Growth index is calculated as the average of plant height plus two-way width at the widest point along the vertical axis of the plant $[(\mathrm{H}+\mathrm{W} 1$ $+\mathrm{W} 2) \div 3$ ]; $\mathbf{n}=12$ for native species, $\mathbf{n}=16$ for both stonecrops. Error bars represent $\mathrm{SE}(1 \mathrm{~cm}=0.3937 \mathrm{inch})$.

rainfall received was $6.5 \mathrm{~cm}$; average daily high temperature was $27.8^{\circ} \mathrm{C}$. High temperature during the 2001 growing season was $34.5^{\circ} \mathrm{C}$, and $7 \mathrm{~d}$ experienced a high greater than 32.2 ${ }^{\circ} \mathrm{C}$. Detailed graphs showing daily precipitation amounts and daily high and low temperatures throughout the study are depicted in Monterusso et al. (2005).

Greater mortality was observed during winter with losses being nearly evenly distributed across treatment levels. Horsemint and black-eyed susan suffered losses of $45 \%$ and $33 \%$, respectively. Smooth aster, junegrass, and showy goldenrod each had one overwintering loss, while lanceleaf coreopsis, 'Diffusum' stonecrop, and 'Royal Pink' stonecrop showed no overwintering mortality. Similar results were found in a companion study conducted at the same time on roof platforms adjacent to the modular units used in this study (Monterusso et al., 2005).
One would expect the perennial native species used in this study to survive a normal winter. However, plants on a green roof do not have the luxury of deep substrates found at ground level that can help insulate the root system. Mortality during winter could very well be due to death of the root systems, which are generally not as cold tolerant as the tops of plants (Wu et al., 2000). Boivin et al. (2001) suggest using a minimum of $10 \mathrm{~cm}$ of substrate on green roofs in northern latitudes $\left(43\right.$ to $\left.60^{\circ} \mathrm{N}\right)$. Even though a shallower substrate would make root systems more susceptible to cold damage, on an actual roof the rooting substrate would be warmed somewhat by heat from the building. During the first winter, we experienced relatively mild temperatures for this area of Michigan. From 22 Dec. 2001 through 20 Mar. 2002 the minimum temperature was $-16.4^{\circ} \mathrm{C}$; the average minimum temperature was $-5.33^{\circ} \mathrm{C}$. Even though the following two winters were more severe, there were no further overwintering losses. Additional losses can most likely be attributed to summer drought, based on visual observations at the end of each growing season. In many cases, the root systems had disintegrated by October.

By May 2004, all plants of smooth aster, horsemint, black-eyed susan, and showy goldenrod were dead (Table 3 ). Junegrass did not fare much better as only two of the 12 original plants survived in the $60 \%$ heat-expanded slate substrate. All junegrass grown at the other four substrate levels suffered $100 \%$ mortality. Half of the lanceleaf coreopsis survived in $60 \%$ and $70 \%$ heat-expanded slate, but only a third of the plants survived in $80 \%, 90 \%$, or $100 \%$. The lower survival rates in the $80 \%, 90 \%$, and $100 \%$ mixtures are likely due to the lower water-holding capacity because of less organic matter in the substrate. Even though lanceleaf coreopsis and the other nonsucculent native perennials evaluated in this study are generally considered drought tolerant, the shallow substrate depths of extensive green roofs limit their normally deep root systems. Of the nonsucculent natives tested, lanceleaf coreopsis appears to have the most potential for use on shallow extensive roofs. This conclusion agrees with that of Monterusso et al. (2005), where the species was deemed suitable not only for its drought tolerance, but also for 

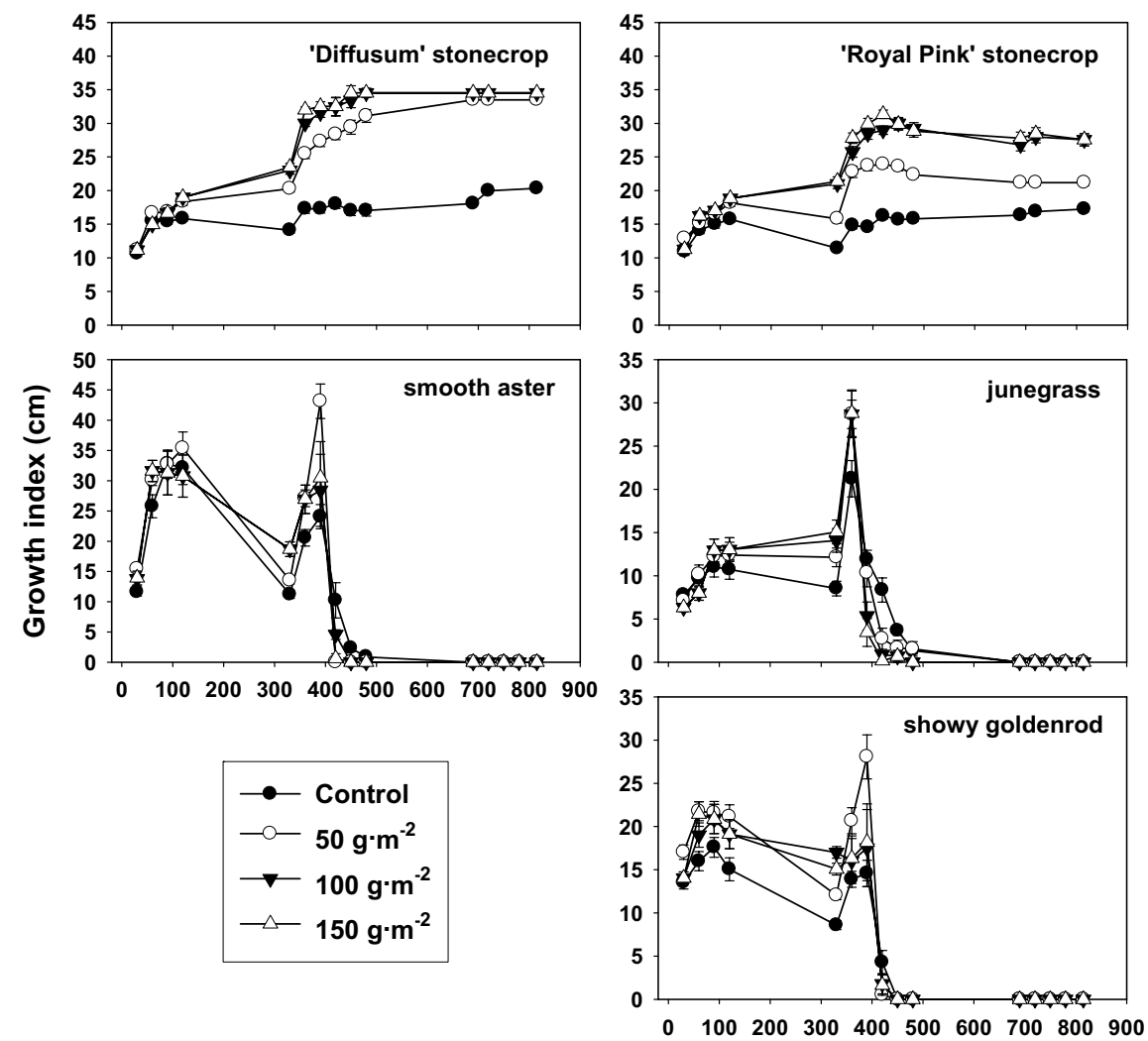

Time after study initiation (d)

Fig. 2. Growth index of two stonecrops and three nonsucculent species native to the midwestern U.S. prairie that were fertilized at four levels of Nutricote 13N-5.7P-10.8K Type 180 controlled-release fertilizer. The substrate was composed of $60 \%$ heat-expanded slate, $25 \%$ U.S. Golf Association-grade sand, $10 \%$ peat, and $5 \%$ compost. Measurements on plant size were taken monthly during three growing seasons. Growth index is calculated as the average of plant height plus two-way width at the widest point along the vertical axis of the plant $[(\mathrm{H}$ $+\mathrm{W} 1+\mathrm{W} 2) / 3] ; \mathbf{n}=\mathbf{1 2}$ for both stonecrops, $\mathbf{n}=\mathbf{1 5}$ for all other species. Error bars represent $\mathrm{SE}\left(1 \mathrm{~g} \cdot \mathrm{m}^{-2}=0.0033 \mathrm{oz} / \mathrm{ft}^{2}, 1 \mathrm{~cm}=0.3937 \mathrm{inch}\right)$.

Table 2. Mean visual rating during July 2002 (day 390) for two stonecrops and six nonsucculent species native to the midwestern U.S. prairie. Plants were grown in five substrates composed of varying percentages of heat-expanded slate.

\begin{tabular}{lccccc}
\hline & \multicolumn{5}{c}{ Visual rating $(\mathbf{0}-\mathbf{5} \text { scale })^{\mathrm{z}}$} \\
\cline { 2 - 6 } Species & $\mathbf{6 0}$ & $\mathbf{7 0}$ & $\mathbf{8 0}$ & $\mathbf{9 0}$ & $\mathbf{1 0 0}$ \\
\cline { 2 - 6 } Smooth aster & $4.23 \mathrm{a}^{\mathrm{x}}$ & $4.55 \mathrm{a}$ & $4.25 \mathrm{a}$ & $3.83 \mathrm{~b}$ & $3.75 \mathrm{~b}$ \\
Lanceleaf coreopsis & $4.44 \mathrm{a}$ & $3.87 \mathrm{~b}$ & $3.91 \mathrm{~b}$ & $3.75 \mathrm{~b}$ & $2.66 \mathrm{c}$ \\
Junegrass & $1.15 \mathrm{a}$ & $1.00 \mathrm{a}$ & $1.33 \mathrm{a}$ & $1.33 \mathrm{a}$ & $1.08 \mathrm{a}$ \\
Horsemint & $0.50 \mathrm{a}$ & $0.30 \mathrm{a}$ & $0.17 \mathrm{a}$ & $0.27 \mathrm{a}$ & $0.17 \mathrm{a}$ \\
Black-eyed susan & $1.60 \mathrm{~b}$ & $0.75 \mathrm{c}$ & $2.58 \mathrm{a}$ & $2.36 \mathrm{a}$ & $1.54 \mathrm{~b}$ \\
'Diffusum' stonecrop & $4.65 \mathrm{a}$ & $4.75 \mathrm{a}$ & $4.75 \mathrm{a}$ & $4.81 \mathrm{a}$ & $4.25 \mathrm{~b}$ \\
'Royal Pink' stonecrop & $4.85 \mathrm{a}$ & $4.92 \mathrm{a}$ & $4.69 \mathrm{a}$ & $4.56 \mathrm{ab}$ & $4.19 \mathrm{~b}$ \\
Showy goldenrod & $2.07 \mathrm{a}$ & $3.00 \mathrm{a}$ & $1.92 \mathrm{a}$ & $2.25 \mathrm{a}$ & $2.42 \mathrm{a}$ \\
\hline
\end{tabular}

${ }^{2}$ Visual rating pertains to the relative appearance of each plant where $0=$ dead, $1=$ stressed plant showing visible wilting or browning, 2 = a plant that showed little change since planting, $3=$ slow growth, $4=$ healthy plant exhibiting a large amount of growth, and $5=$ exceptional growth and fullness.

yermaTill (Carolina Stalite, Salisbury, N.C.) with a particle size ranging from 7.9 to $9.5 \mathrm{~mm}(0.31-0.37$ inch). The $60 \%$ substrate is composed of $60 \%$ heat-expanded slate, $25 \%$ U.S. Golf Association-grade sand, $10 \%$ peat, and $5 \%$ compost. The $70 \%, 80 \%, 90 \%$, and $100 \%$ substrates have proportional decreases in sand, peat, and compost.

${ }^{x}$ Mean separation in rows between substrate composition within each species were tested using chi-square tests at $P \leq 0.05 ; \mathrm{n}=16$ for both stonecrop species, $\mathrm{n}=12$ for all other species. its ability to naturalize by seed. Both stonecrops already achieved $100 \%$ coverage in June 2002 and had maintained this coverage into 2004.

Higher levels of heat-expanded slate in the substrate generally resulted in slightly less growth and lower visual ratings across all species, although the differences were not pronounced. This finding suggests that a moderately high level of heat-expanded slate $(70 \%$ to $80 \%$ ) can be incorporated into the growing substrate without sacrificing plant vigor. Heat-expanded slate contents higher than $80 \%$ could be utilized if the species planted are dominated by stonecrops evaluated in this study. If the nonsucculent natives evaluated in this study are utilized, then deeper substrates, additional organic matter, or supplemental irrigation are necessary. Another consideration when comparing the growth indices is the differences in substrate composition between the treatments with regard to the compost content. As stated above, growth was found to be inversely related to heat-expanded slate content, but growth could also be considered to be directly related to the amount of organic material in the growing substrate. However, high levels of compost are not recommended because the compost will decompose, resulting in substrate shrinkage (Beattie and Berghage, 2004) and increased N and $\mathrm{P}$ in the runoff (Emilsson, 2004; Moran et al., 2005).

Fertilizer study. In general, plants that received no fertilizer produced the least amount of growth (Fig. 2). This was true for both stonecrops, but was not always true for the native perennials $(P \leq 0.05)$. 'Diffusum' stonecrop grown at $50 \mathrm{~g} \cdot \mathrm{m}^{-2}$ lagged behind the 100 and $150 \mathrm{~g} \cdot \mathrm{m}^{-2}$ treatments until the third year, when the $50 \mathrm{~g} \cdot \mathrm{m}^{-2}$ treatment achieved a growth index rating equal to the higher rates of fertilizer. In contrast, plants of 'Royal Pink' stonecrop receiving 50 $\mathrm{g} \cdot \mathrm{m}^{-2}$ never obtained the same growth as the 100 or $150 \mathrm{~g} \cdot \mathrm{m}^{-2}$ rates $(P \leq$ $0.05)$. This suggests that 'Royal Pink' stonecrop may have greater fertility requirements. Even so, both species continued to expand without supplemental fertilizer. At the higher fertilizer rates, stonecrop growth leveled off as the plants reached $100 \%$ coverage and it became difficult to distinguish individual plants within each species. However, because 'Diffusum' stone- 
Table 3. Percent survival in May 2004 (day 1065) for two stonecrops and six nonsucculent species native to the midwestern U.S. prairie. Plants were grown in five substrates composed of varying percentages of heat-expanded slate. Values indicate survival of original plugs planted 15 June 2001.

\begin{tabular}{lccccc}
\hline & \multicolumn{5}{c}{ Survival (\%) } \\
\cline { 2 - 6 } Species & 60 & 70 & 80 & 90 & 100 \\
\cline { 2 - 6 } Smooth aster & 0 & 0 & 0 & 0 & 0 \\
Lanceleaf coreopsis & $50 \mathrm{a}^{\mathrm{y}}$ & $50 \mathrm{a}$ & $33 \mathrm{~b}$ & $33 \mathrm{~b}$ & $33 \mathrm{~b}$ \\
Junegrass & $17 \mathrm{a}$ & $0 \mathrm{~b}$ & $0 \mathrm{~b}$ & $0 \mathrm{~b}$ & $0 \mathrm{~b}$ \\
Horsemint & 0 & 0 & 0 & 0 & 0 \\
Black-eyed susan & 0 & 0 & 0 & 0 & 0 \\
'Diffusum' stonecrop & $100 \mathrm{a}$ & $100 \mathrm{a}$ & $100 \mathrm{a}$ & $100 \mathrm{a}$ & $100 \mathrm{a}$ \\
'Royal Pink' stonecrop & $100 \mathrm{a}$ & $100 \mathrm{a}$ & $100 \mathrm{a}$ & $100 \mathrm{a}$ & $100 \mathrm{a}$ \\
Showy goldenrod & 0 & 0 & 0 & 0 & 0
\end{tabular}

${ }^{2}$ PermaTill (Carolina Stalite, Salisbury, N.C.) with a particle size ranging from 7.9 to $9.5 \mathrm{~mm}(0.31-0.37$ inch) The $60 \%$ substrate is composed of $60 \%$ heat-expanded slate, $25 \%$ U.S. Golf Association-grade sand, $10 \%$ peat, and $5 \%$ compost. The $70 \%, 80 \%, 90 \%$, and $100 \%$ substrates have proportional decreases in sand, peat, and compost. yean separation in rows between substrate composition within each species were tested using chi-square tests at $P \leq 0.05 ; \mathrm{n}=16$ for both stonecrop species, $\mathrm{n}=12$ for all other species.

Table 4. Mean visual rating during July 2002 (day 390) for two stonecrop and three nonsucculent species native to the midwestern U.S. prairie grown in a substrate composed of $60 \%$ heat-expanded slate, $25 \%$ sand, $10 \%$ peat, and $5 \%$ compost. Plants were fertilized at four levels of Nutricote $13 \mathrm{~N}-5.7 \mathrm{P}-10.8 \mathrm{~K}$ Type 180 controlled-release fertilizer.

\begin{tabular}{|c|c|c|c|c|}
\hline \multirow[b]{3}{*}{ Species } & \multicolumn{4}{|c|}{ Visual rating $(0-5 \text { scale })^{\mathrm{z}}$} \\
\hline & \multicolumn{4}{|c|}{ Fertilizer application rate $\left(\mathrm{g} \cdot \mathrm{m}^{-2}\right)^{\mathrm{y}}$} \\
\hline & 0 (control) & 50 & 100 & 150 \\
\hline mooth aster & $2.73 b^{x}$ & $4.07 \mathrm{a}$ & $3.67 \mathrm{a}$ & $3.40 \mathrm{ab}$ \\
\hline Junegrass & $1.87 \mathrm{a}$ & $1.60 \mathrm{a}$ & $0.87 \mathrm{~b}$ & $0.47 \mathrm{c}$ \\
\hline 'Diffusum' stonecrop & $2.08 \mathrm{~b}$ & $4.33 \mathrm{a}$ & $4.67 \mathrm{a}$ & $4.58 \mathrm{a}$ \\
\hline 'Royal Pink' stonecrop & $1.67 \mathrm{c}$ & $3.67 \mathrm{~b}$ & $4.58 \mathrm{a}$ & $4.50 \mathrm{a}$ \\
\hline Showy goldenrod & $2.13 \mathrm{bc}$ & $3.27 \mathrm{a}$ & $2.47 \mathrm{~b}$ & $1.87 \mathrm{c}$ \\
\hline \multicolumn{5}{|c|}{$\begin{array}{l}{ }^{2} \text { Visual rating pertains to the relative appearance of each plant where } 0=\mathrm{dead}, \mathrm{l}=\text { stressec } \\
\text { plant showing visible wilting or browning, } 2=\text { a plant that showed little change since planting } \\
3=\text { slow growth, } 4=\text { healthy plant exhibiting a large amount of growth, and } 5=\text { exceptiona } \\
\text { growth and fullness. } \\
{ }^{1} \mathrm{~g} \cdot \mathrm{m}^{-2}=0.0033 \mathrm{oz} / \mathrm{ft}^{2} \text {. } \\
{ }^{\mathrm{N}} \text { Mean separation in rows between fertilizer application rates within each species were tested } \\
\text { using chi-square tests at } P \leq 0.05 ; \mathrm{n}=12 \text { for both stonecrop species, } \mathrm{n}=15 \text { for all other } \\
\text { species. }\end{array}$} \\
\hline
\end{tabular}

Table 5. Percent survival during July 2002 (day 390) for two stonecrops and three nonsucculent species native to the midwestern U.S. prairie grown in a substrate composed of $60 \%$ heat-expanded slate, $25 \%$ sand, $10 \%$ peat, and $5 \%$ compost. Plants were fertilized at four levels of Nutricote $13 \mathrm{~N}-5.7 \mathrm{P}-10.8 \mathrm{~K}$ Type 180 controlled-release fertilizer. Values indicate survival of original plugs planted 15 June 2001.

\begin{tabular}{lcccr}
\hline & \multicolumn{4}{c}{ Survival (\%) } \\
\cline { 2 - 5 } Species & \multicolumn{4}{c}{ Fertilizer application rate $\left(\mathbf{g} \cdot \mathbf{m}^{-2}\right)^{\mathbf{z}}$} \\
\cline { 2 - 5 } Smooth aster & $60 \mathrm{a}^{\mathrm{y}}$ & $7 \mathrm{~b}$ & $13 \mathrm{~b}$ & $7 \mathrm{~b}$ \\
Junegrass & $80 \mathrm{a}$ & $27 \mathrm{~b}$ & $20 \mathrm{~b}$ & $13 \mathrm{~b}$ \\
'Diffusum' stonecrop & $100 \mathrm{a}$ & $100 \mathrm{a}$ & $100 \mathrm{a}$ & $100 \mathrm{a}$ \\
'Royal Pink' stonecrop & $100 \mathrm{a}$ & $100 \mathrm{a}$ & $100 \mathrm{a}$ & $100 \mathrm{a}$ \\
Showy goldenrod & $47 \mathrm{a}$ & $13 \mathrm{~b}$ & $13 \mathrm{~b}$ & $13 \mathrm{~b}$ \\
\hline${ }^{2} 1$ g.m-2 ${ }^{-2}=0.0033$ oz $/ \mathrm{ft}^{2}$. & & & & \\
'Mean separation in rows between fertilizer application rates within each species were tested \\
using chi-square tests at $P \leq 0.05 ; \mathrm{n}=12$ for both stonecrop species, $\mathrm{n}=15$ for all other \\
species.
\end{tabular}

crop was more aggressive, it began to displace 'Royal Pink' stonecrop due to competition. In the control, 'Royal Pink' stonecrop continued to increase in size because it was not crowded by 'Diffusum' stonecrop.

The native species did not show any consistent response to the various fertilizer applications (Fig. 2). The relatively low rate of $50 \mathrm{~g} \cdot \mathrm{m}^{-2}$ resulted in the highest growth index for both smooth aster and showy goldenrod at day 390 during the second season, but the control still resulted in the least amount of growth. When supplemental irrigation was terminated during the second season, the absence of irrigation was detrimental for all three native species, but had minimal effect on either stonecrop.

The absence of fertilizer had a pronounced effect on both stonecrops as their visual ratings were much higher at 50,100 , and $150 \mathrm{~g} \cdot \mathrm{m}^{-2}$ compared to the control (Table 4 ). In contrast, there was no common trend for the three natives. In fact, junegrass and showy goldenrod performed the worst at the highest fertilizer level. The higher fertility levels encouraged greater growth when sufficient moisture was available, but as the plants dried out with the onset of hot summer days, the dried-out foliage was not aesthetically pleasing. However, stonecrop was relatively unaffected during drought periods and clearly outperformed the nonsucculent natives. Overall, both 'Diffusum' stonecrop and 'Royal Pink' stonecrop showed the best results visually of all species tested, as well as displaying the best drought tolerance after the termination of irrigation. This finding supports the concept that stonecrop can be used in a wide variety of conditions and will grow successfully, particularly in dry areas (Heinz, 1985; Kutkova, 1990; Zhao et al., 2001).

Survival rates associated with the various fertilizer treatments for all species were high during the establishment period and initial overwintering (data not presented). During establishment, the only species to suffer mortality was junegrass with two plants dying, one in $50 \mathrm{~g} \cdot \mathrm{m}^{-2}$ and one in $150 \mathrm{~g} \cdot \mathrm{m}^{-2}$. By day 390 , all plants of both stonecrops were still alive, but significant losses had occurred in the natives (Table 5 ). An interesting observation is that a significantly higher number of smooth aster, junegrass, and showy goldenrod 
plants survived when they were not fertilized. Presumably, these plants could survive drought conditions for a longer period of time since they had less biomass to maintain. However, by the end of three growing seasons (day 1065), all three natives were dead. Survival of the natives was more a function of water availability than fertility; however, low fertility did increase survival. In contrast, stonecrop sustained $100 \%$ coverage after 3 years. The plants of stonecrop that were not being fertilized appeared stressed, but there was no mortality associated with this treatment.

Results show that plants evaluated in this study do not perform well in the absence of fertilizer, but only a minimal amount $\left(50 \mathrm{~g} \cdot \mathrm{m}^{-2}\right)$ is required to sustain plant health. The use of a fertilizer rate above $50 \mathrm{~g} \cdot \mathrm{m}^{-2}$ does not result in benefits sufficient to justify its use. Applying more fertilizer than required results in potential leaching of $\mathrm{N}, \mathrm{P}$, and other nutrients into stormwater runoff. By reducing the amount of organic matter in the substrate and by applying the minimal amount of fertilizer to maintain plant health, contaminated discharge from green roofs can be reduced considerably (Emilsson, 2004; Moran et al., 2005). Also, if any of the native species tested are to be utilized in a rooftop planting in the midwestern U.S., then supplemental irrigation may be required to maintain sufficient survival and coverage.

Conclusion. Results suggest that moderately high levels of heatexpanded slate (up to $80 \%$ ) can be incorporated into a green roof growing substrate when growing succulents, such as stonecrop, without sacrificing plant health and at the same time reducing the load placed on a building. By the end of the second season, both stonecrops had reached $100 \%$ coverage regardless of substrate composition. Higher levels of heat-expanded slate could be used if the majority of the species used are stonecrop. However, the nonsucculents used in this study require deeper substrates, additional organic matter, or supplemental irrigation. Deeper substrates are beneficial for both increased water-holding capacity and as a buffer for overwintering survival. In general, plants that received no fertilizer produced the least amount of growth, but the three nonsucculent native species exhibited higher survival rates when they were not fertilized. Excluding overwintering cold tolerance, survival of the natives was more a function of water availability than fertility; however, low fertility did increase survival. Some fertilizer is necessary to maintain plant health when grown in a typical green roof substrate, although the amount required is minimal-possibly less than $50 \mathrm{~g} \cdot \mathrm{m}^{-2}$ per year.

\section{Literature cited}

Beattie, D.J. and R. Berghage. 2004. Green roof media characteristics: The basics, p. 411-416. Proc. 2nd North Amer. Green Roof Conf.: Greening Rooftops for Sustainable Communities, Portland, Ore. 2-4 June 2004. Cardinal Group, Toronto.

Bilderback, T.E., S.W. Warren, J.S. Owen, Jr., and J.P. Albano. 2005. Healthy substrates need physicals too! HortTechnology 15:747-751.

Boivin, M., M. Lamy, A. Gosselin, and B. Dansereau. 2001. Effect of artificial substrate depth on freezing injury of six herbaceous perennials grown in a green roof system. HortTechnology 11:409-412.

Clark, C., B. Talbot, J. Bulkley, and P. Adriaens. 2005. Optimization of green roofs for air pollution mitigation, p. 482-597. In: Proc. 3rd North Amer. Green Roof Conf.: Greening Rooftops for Sustainable Communities, Washington, D.C. 4-6 May 2005. Cardinal Group, Toronto.

Connelly, M. and K. Liu. 2005. Green roof research in British Columbia-An overview, p. 416-432. Proc.3rd North Amer. Green Roof Conf.: Greening Rooftops for Sustainable Communities, Washington, D.C. 4-6 May 2005. Cardinal Group, Toronto.

Dunnett, N. and A. Nolan. 2004. The effect of substrate depth and supplementary watering on the growth of nine herbaceous perennials in a semi-extensive green roof. Acta Hort. 643:305-309.

Dunnett, N. and N. Kingsbury. 2004. Planting green roofs and living walls. Timber Press, Portland, Ore.

Durhman, A., N.D. VanWoert, D.B. Rowe, C.L. Rugh, and D. Ebert. May. 2004. Evaluation of Crassulacean species on extensive green roofs, p. 504-517. Proc. 2nd North Amer. Green Roof Conf.: Greening Rooftops for Sustainable Communities, Portland, Ore. 2-4 June 2004. Cardinal Group, Toronto.

Emilsson, T. 2004. Impact of fertilisation on vegetation development and water quality, $\mathrm{p}$. 541-548. Proc. 2nd North Amer. Green Roof Conf:: Greening Rooftops for Sustainable Communities, Portland, Ore. 2-4 June 2004. Cardinal Group, Toronto.

Friedrich, C.R. 2005. Principles for selecting the proper components for a green roof growing media, p. 262-273. Proc. 3rd North Amer. Green Roof Conf.: Greening Rooftops for Sustainable Communities, Washington, D.C. 4-6 May 2005. Cardinal Group, Toronto.
Giesel, D. 2001. Grün auf das dachkosten in den keller? Stadt und Grün 50:404-406.

Heinz, W. 1985. Results of an experiment on extensive growth of vegetation on roofs. Rasen Grunflachen Begrunungen 16(3):80-88.

Jauch, M. 1993. Extensive Dachbegruenung. Die Fetten sind nicht fit genug. DeutscherGartenbau 47(1):36-37.

Kutkova, T. 1990. Herbaceous plants for sites with extreme conditions in landscape architecture. Acta Universitalis Agr. 5(1):67-73.

Liesecke, H.J. 1998. Das retentionsvermögen von dachbegrünungen. Stadt und Grün $47(1): 46-53$

Monterusso, M.A., D.B. Rowe, and C.L. Rugh. 2005. Establishment and persistence of Sedum spp. and native taxa for green roof applications. HortScience 40:391-396.

Moran, A., B. Hunt, and J. Smith. 2005. Hydrologic and water quality performance from green roofs in Goldsboro and Raleigh, North Carolina, p. 512-525. Proc. 3rd North Amer. Green Roof Conf.: Greening Rooftops for Sustainable Communities, Washington, D.C. 4-6 May 2005. Cardinal Group, Toronto.

Rowe, D.B., C.L. Rugh, N. VanWoert, M.A Monterusso, and D.K. Russell. 2003. Green roof slope, substrate depth, and vegetation influence runoff, p. 354-362. Proc. 1st North Amer. Green Roof Conf.: Greening Rooftops for Sustainable Communities, Chicago. 29-30 May 2003. Cardinal Group, Toronto.

Rowe, D.B., M.A. Monterusso, and C.L. Rugh. 2005. Evaluation of Sedum spp. and Michigan native taxa for green roof applications, $\mathrm{p}$. 469-481. Proc. 3rd North Amer. Green Roof Conf.: Greening Rooftops for Sustainable Communities, Washington, D.C. 4-6 May, 2005. Cardinal Group, Toronto.

Saiz-Alcazar, S. and B. Bass. 2005. Energy performance of green roofs in a multi storey residential building in Madrid, p. 569-582. Proc. 3rd North Amer. Green Roof Conf: Greening Rooftops for Sustainable Communities, Washington, D.C. 4-6 May 2005. Cardinal Group, Toronto.

Schade, C. 2000. Wasserrückhaltung und Abflußbeiwerte bei dünnschichtigen extensivbegrünungen. Stadt und Grün 49(2):95-100.

VanWoert, N.D, D.B. Rowe, J.A. Andresen, C.L. Rugh, R.T. Fernandez, and L. Xiao. 2005a. Green roof stormwater retention: Effects of roof surface, slope, and media depth. J. Environ. Quality 34:1036-1044.

VanWoert, N.D, D.B. Rowe, J.A. Andresen, C.L. Rugh, and L. Xiao. 2005b. Watering regime and green roof substrate design affect Sedum plant growth. HortScience 40:659-664.

Wu, Y., D. Cosgrove, B. Davies, B. Sharp. 2000. Adaptation of roots to low water potentials by changes in cell wall extensibility and cell wall proteins. J. Expt. Bot. 51(300):1543-1553.

Zhao, D., L. Qiao, A. Xia, X. XinNong, H. RongHua, J. KaiHua, and G. Lu. 2001. A good plant suitable for roof greening-Preliminary investigation Sedum lineare. Acta Agriculturea Shanghai 17(4):58-59. 